\title{
Mackenzie, Louisa.
}

\section{The Poetry of Place: Lyric, Landscape, and Ideology in Renaissance France.}

Toronto, Buffalo, and London: University of Toronto Press, 2011. Pp. xi, 324. ISBN 978-1-4426-4239-3 (hardcover) \$65.

Louisa Mackenzie's study of the relationship between poetry and place in France in the second half of the sixteenth century is an original, thought-provoking contribution to our understanding of both the literature and history of early modern France. Methodologically rigorous, theoretically informed yet fluently written, this is a literary study conceived in fruitful dialogue with history, geography, and the history of art, and deserving broad readership. Steeped in criticism and Renaissance letters alike, it wears its considerable learning lightly. Like many book-length literary studies, Mackenzie's monograph is organized around chapter-length case studies of canonical texts, yet she has asked her questions and chosen her material to serve a strong, coherent, and stimulating argument.

In a period of intense political and religious turmoil, how did poets describe France's landscape? As the monarchy sought to tighten its grip on a culturally diverse kingdom and to annex new territories, how did poets reconcile the national with the local? In a society that venerated Virgil's Eclogues, what precisely did Arcadia represent for men of letters? What did a timeless pastoral ideal mean to poets who hailed from a landed aristocratic class at a particularly vexed historical moment? These are questions that Mackenzie imaginatively poses, and to which she ably offers answers.

Mackenzie's first chapter lays out the methodological parameters of her study. She defines the object of her analysis to be landscape, conceived as the way in which people perceive and describe nature, while her goal is to help reconstruct its cultural history. Socially constructed and historically specific, landscape must be seen as "necessarily ideological" (p. 26).

In the five chapters that follow, Mackenzie examines how French poets used lyric landscape to explore these questions. Chapter 2 excavates the lively dialogue between poets (who wrote about maps) and cartographers (who included verse in their maps) as they sought ways to represent France as a cohesive kingdom. Maps and poetry thus worked "together in specific ways to imagine place in the French sixteenth century" (p. 50). 
In chapter 3, Mackenzie explores how Joachim Du Bellay imagined a double French and Angevin identity. In a poetic conversation equally engaged with Greco-Roman Antiquity, with Virgil's bucolic universe, with Rome as place and site of memory, and with Petrarch's lyric, Du Bellay describes the local and the national as dialectically and mutually constitutive.

Chapter 4 examines the relationship between poetry and painting in Pontus de Tyard and Rémy Belleau's verse. Mackenzie argues that Renaissance poets adopt a Mannerist mode when writing about painting landscapes in order to draw attention to the very exercise of representation as well as to emphasize its limits. As Mackenzie puts it, this "Mannerist sensibility ... disrupts the stability and coherence of its landscapes" and "dramatizes the impossibility of naming and describing France" (p. 92). Painting thus offers poets a theme for lyric uniquely suited to deconstructing the very notion of landscape and to demonstrating the challenges of representing the French kingdom.

Chapter 5 considers poetic engagement with environmental change. Mackenzie first considers how Jean-Antoine de Baif laments the pollution of the Bièvre river near Paris, due to the greed of tanners and dyers. She compares this to Pierre de Ronsard's verse bemoaning the depravations inflicted by woodcutters upon the forests of the Gâtinais, a region to which his family had long connections. She connects his plaint to a broader historical context: these forests belonged to Henri de Bourbon, Protestant leader and future Henri IV, who sold these lands off to pay debts incurred in the religious conflict. Mackenzie demonstrates that Baif and Ronsard's sylvan nostalgia rests not upon a proto-environmentalist outlook, but rather upon a conservative social and political ideology in the face of challenges to local identities and Catholic noble landowners' social positions.

In chapter 6, Mackenzie explores how poets created landscapes to serve as sites for optimism embodying conservative ideals in response to disconcerting historical change. By describing his own family's lands, Vauquelin de la Fresnaye's poetry posits forests as the foundation for an idealized aristocratic identity. He describes the forest as both Arcadia and real property owned and exploited by his family, who because of economic difficulties must contemplate its sale: "Thus, autobiographical fact and social anxiety contaminate the poetic landscape that he is trying to construct as his own" (p. 172). She closes this chapter by considering how Jacques Peletier du Mans celebrated the thenindependent polity Savoy as a refuge from the religious and political storms 
sweeping France in ways that explicitly acknowledged landscapes to be constructions of human perception.

In her conclusion, Mackenzie argues that the grim experience of the Wars of Religion transformed landscape's grip on poets' imaginations. As optimism gave way to pessimism, landscapes could no longer function as sites for imagining "spaces of hope," and instead became places of retreat from a violent and uncertain world. No longer rooted in place, pastoral became a metaphysical space. Her book therefore studies a short-lived poetic experiment: the attempt by poets to imagine a bright future for a coherent French territory despite the ravages of religious conflict.

It is a pity that, in an otherwise nicely-produced book, University of Toronto Press did not see fit to include illustrations in the discussions of cartography and painting in chapters two and three. A few glitches have snuck their way in: although Mackenzie has judiciously included English translations for all quoted verse, one Du Bellay poem goes untranslated (p. 60); nobility brought exemption from the taille, not the gabelle (p. 151).

Mackenzie's excellent book offers a sophisticated model for reading poetry in light of social status, the socioeconomic conditions for the production of verse, political context, and poetry's internal cultural logics. She demonstrates lyric landscapes to be expressions of the desires, ideologies, and interests of the leisured landed aristocratic class from which poets were drawn and to which they were attached. She calls on us to think about early modern landscapes in a new way: as a site for nobles' anxieties about the future in the face of political, social, and economic upheaval.

PAUl COHEN, University of Toronto 